\title{
ON THE ISSUE OF EFFICIENCY OF THERMAL METHODS APPLICATION FOR INTENSIFICATION OF HARD-TO-RECOVER BITUMINOUS OILS PRODUCTION
}

\author{
К ВОПРОСУ ОБ ЭФФЕКТИВНОСТИ ПРИМЕНЕНИЯ \\ ТЕПЛОВЫХ МЕТОДОВ ИНТЕНСИФИКАЦИИ ДОБЫЧИ \\ ТРУДНОИЗВЛЕКАЕМЫХ БИТУМНЫХ НЕФТЕЙ
}

\section{Alina A. Gizzatullina}

\section{А. А. Гиззатуллина}

Ufa State Petroleum

Technological University,

Branch, Oktyabrsky,

Republic of Bashkortostan,

Russian Federation

Уфимский государственный

нефтяной технический

университет,

филиал, г. Октябрьский,

Республика Башкортостан,

Российская Федерация

\section{Yulia A. Tazetdinova \\ Ю. А. Тазетдинова}

Bashkir State University, Branch, Birsk, Republic of Bashkortostan, Russian Federation

\author{
Башкирский государственный \\ университет, \\ филиал, г. Бирск, \\ Республика Башкортостан, \\ Российская Федерация
}

\section{Bulat I. Tazetdinov \\ Б. И. Тазетдинов}

Bashkir State University, Branch, Birsk, Republic of Bashkortostan, Russian Federation

Башкирский государственный университет, филиал, г. Бирск, Республика Башкортостан, Российская Федерация

\section{Key words}

high-viscosity oil using the technology of paired horizontal wells, operating alternately and located in parallel, is proposed. The upper well is a heating well, through which the heat carrier flows, and the lower one is a production well, through which the product is taken. A system of differential equations for pressure and temperature taking into account the gravitational effect is obtained. Numerical solutions of the problem are constructed in a two-dimensional formulation by the method of finite differences according to an explicit scheme. Using this method of highviscosity oil production, the efficiency of developing an oil reservoir can be increased by ensuring uniform heating of the developed zone of the field. The proposed model makes it possible to trace the two-dimensional picture of oil filtration in the reservoir and to study the basic laws of the process. The costs for heating the oil reservoir, the evolution of the well flow rate and changes in the mass of pumped oil in the initial period of the well operation are determined. The obtained solutions were extrapolated for longer periods. The results obtained make it possible to give an approximate picture of thermal impact effectiveness on the reservoir due to its geological and physical characteristics.

Предложена теоретическая модель процесса разработки нефтяного пласта с высоковязкой нефтью при помощи технологии парных горизонтальных скважин, работающих попеременно и расположенных параллельно между собой. Верхняя скважина является обогревающей, по которой течет теплоноситель, а нижняя - добывающая скважина, через которую ведется отбор продукции. Получена система дифференциальных уравнений для давления и температуры с учетом гравитационного эффекта. Построены численные решения задачи в двумерной постановке методом конечных разностей по явной схеме. При таком способе добычи высоковязкой нефти эффективность разработки нефтяного пласта может быть увеличена за счет обеспечения равномерного прогрева осваиваемой зоны месторождения. Предложенная модель позволяет проследить двумерную картину фильтрации нефти в пласте и исследовать основные закономерности процесса. Определены затраты на прогревание нефтяного пласта, эволюция дебита скважины и изменения массы откачиваемой нефти в начальный период эксплуатации скважины.

\section{Ключевые слова}

высоковязкая нефть; битум; тепловое воздействие

на нефтяной пласт; фильтрация нефти; нефтяной пласт 
Проведена экстраполяция полученных решений на более длительные времена. Полученные результаты позволяют дать ориентировочную картину об эффективности теплового воздействия на пласт в зависимости от его геолого-физических особенностей.

\section{Introduction}

The depletion of light conventional oil reserves, as well as a continuous increase in prices, cause genuine interest in high-viscosity and bitumen oil fields. For this reason, the technologies for the extraction of unconventional sources of hydrocarbon crude are actively developed. Highgravity oil pools repeatedly exceed low-viscosity and light crude reserves, with that accounting for a sizable proportion of oil industry raw material base. The development of heavy and high-viscosity oil deposits is currently considered to be a promising area, not only because the reserves in such fields are large, but also because many of these oils are valuable raw materials for the chemical industry. A great part of modern technologies for the development of high-viscosity oil fields is more or less associated with the heating of raw materials to reduce its viscosity, which improves its mobility. Horizontal flue implementation technology has shown its efficiency [1-4].

A mathematical model and numerical solutions for the two-dimensional problem of a reservoir production with unconventional oil using the technology of a pair of horizontal wells operating alternately has been constructed in this article.

Problem statement and basic equations

Let us assume that an oil-saturated reservoir with thickness $H$ is located above an impermeable rock $(y=0)$. At the top $\left(\mathrm{y}^{(0)}=H\right)$ it borders on a porous rock are saturated with a less viscous fluid, for example, water. There are two parallel horizontal wells installed one below the other. However, the upper well with radius $a^{(T)}$ is heating one, along which the thermal fluid flows, the lower one is the flowing well with radius $a^{(p)}$, into which oil enters. Assume that the pressure and temperature differentials in the plane in the direction parallel to the axis of the wells are next to none, compared to the direction to the axis of the wells. Due to this, the filtration rate and the heat flux vector will lay in a plane perpendicular to the axes of the wells and, therefore, the hydrodynamic and termal fields in the plane will be described by the filter and heat conduction equations in two-dimensional approach (the plane section hypothesis is accepted [5]). For a theoretical description of the reservoir production process, let us assume the rectangular coordinate system (Figure 1).

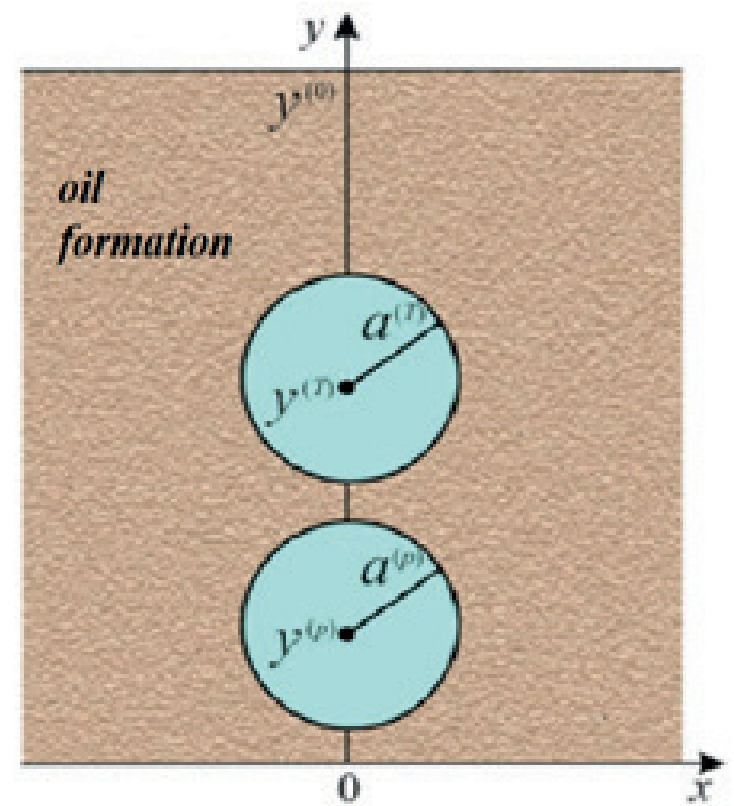

Figure 1. The arrangement of horizontal wells in a rectangular coordinate system

The symmetric property of the layer geometry allows limiting to calculations, for example, to the right half of the area. We may write the continuity and heat flow equation for an oil reservoir $\left(0<x<\infty, 0<y<y^{(0)}\right)[6]$ :

$$
\begin{aligned}
& \frac{\partial m \rho_{l}}{\partial t}+\frac{\partial}{\partial x}\left(m \rho_{l} v_{x}\right)+\frac{\partial}{\partial y}\left(m \rho_{l} v_{y}\right)=0, \\
& \rho c \frac{\partial T}{\partial t}+\rho_{l} m c_{l} v_{x} \frac{\partial T}{\partial x}+ \\
& +\rho_{l} m c_{l} v_{y} \frac{\partial T}{\partial y}=\lambda\left(\frac{\partial^{2} T}{\partial x^{2}}+\frac{\partial^{2} T}{\partial y^{2}}\right),
\end{aligned}
$$

where $\lambda$ - thermal conductance;

$$
\begin{aligned}
& \rho c-\text { specific heat of the reservoir; } \\
& m \text { - porosity; } \\
& T \text { - formation temperature; } \\
& v \text { - oil rate; } \\
& \rho_{l} \text { and } c_{l} \text { - oil density and oil specific heat. }
\end{aligned}
$$

For a mathematical description of the oil filtration rate, let us use the Darcy law, and in order to take into account the gravitational force, we write the generalized Darcy law:

$$
\begin{gathered}
m v_{x}=-\frac{k}{\mu(T)} \frac{\partial p}{\partial x} \\
m v_{y}=-\frac{k}{\mu(T)}\left(\frac{\partial p}{\partial y}+\rho_{l} g\right) .
\end{gathered}
$$

Here $k$ - permeability of the porous medium; 
$p$ - pressure;

$g$ - gravity acceleration;

$\mu-$ dynamic oil viscosity, for the dependence of which on the temperature the expression $\mu(T)=\mu_{0}^{e-\gamma(T-T 0)}$ is accepted.

We write the functional relation for pressure in the form $P=p+\rho_{l} g y$. In this case, the second expression from (2) can be represented as

$$
m v_{y}=-\frac{k}{\mu(T)}\left(\frac{\partial P}{\partial y}\right) .
$$

The equation of state for oil can be written in a linear approximation $[1,7]$ :

$$
\rho_{l}=\rho_{l 0}\left(1-\alpha^{(T)}\left(T-T_{0}\right)+\alpha^{(p)}\left(p-p_{0}\right)\right) .
$$

Here the lower index 0 corresponds to the initial values of the oil parameters, $\alpha^{(T)}$ and $\alpha^{(p)}$ - thermal coefficient of expansion and compressibility of oil.

From equations (1) - (4) we get expressions, which describe the pressure and temperature:

$$
\begin{gathered}
\frac{\partial P}{\partial t}=\frac{\alpha^{(T)}}{\alpha^{(p)}} \frac{\partial T}{\partial t}+\frac{k}{m \alpha^{(p)}}\left(\frac{\partial}{\partial x}\left(\frac{1}{\mu(T)} \frac{\partial P}{\partial x}\right)+\right. \\
\left.+\frac{\partial}{\partial y}\left(\frac{1}{\mu(T)} \frac{\partial P}{\partial y}\right)\right) \\
\frac{\partial T}{\partial t}=\frac{k \rho_{l} c_{l}}{\mu(T) \rho c}\left(\frac{\partial P}{\partial x} \frac{\partial T}{\partial x}+\frac{\partial P}{\partial y} \frac{\partial T}{\partial y}\right)+ \\
+v\left(\frac{\partial^{2} T}{\partial x^{2}}+\frac{\partial^{2} T}{\partial y^{2}}\right)
\end{gathered}
$$

Here $v=\lambda /(\rho c)$ is the temperature conductivity coefficient of the reservoir. The resulting system of equations (5) makes it possible to model the dynamics of pressure and temperature in the oil reservoir and thus describe a two-dimensional picture of the unconventional oil extraction process.

Let us assume that in the initial state in the reservoir, the pressure obeys a hydrostatic distribution, and the temperature is distributed evenly. Then we can write down:

$$
\begin{gathered}
P=p_{0}+\rho_{l} g\left(y^{(0)}-y\right), \\
T=T_{0} \quad\left(t \leq 0,-\infty<x<\infty, \quad 0<y<y^{(0)}\right) .
\end{gathered}
$$

Taking into account the above assumptions, the boundary conditions can be written as

$$
\begin{aligned}
& \partial P / \partial y=0 \\
& (t>0,-\infty<x<\infty, \quad y=0) \text {, } \\
& P=p_{0} \\
& \left(t>0,-\infty<x<\infty, \quad y=y^{(0)}\right), \\
& P=p_{0}+\rho_{l} g\left(y^{(0)}-y\right) \\
& \left(t \leq 0, x= \pm \infty, \quad 0<y<y^{(0)}\right) \text {, } \\
& P=p_{c}+\rho_{l} g\left(y^{(0)}-y\right), \\
& \partial T / \partial n=0 \\
& \left(t>0, x^{2}+\left(y-y^{(p)}\right)^{2}=a^{(p)^{2}}\right), \\
& \partial P / \partial n=0, \\
& T=T_{e} \quad\left(t>0, x^{2}+\left(y-y^{(T)}\right)^{2}=a^{(T)^{2}}\right), \\
& T=T_{0} \quad\left(t>0,-\infty<x<\infty, y=0, y^{(0)}\right) .
\end{aligned}
$$

Here $\partial T / \partial n=\partial T / \partial x \cdot n_{x}^{(T)}+\partial T / \partial y \cdot n_{y}^{(T)}$,

$$
\partial P / \partial n=\partial P / \partial x \cdot n_{x}^{(p)}+\partial P / \partial y \cdot n_{y}^{(p)},
$$

where $\quad n_{x}^{(T)}=x / a^{(T)}, n_{x}^{(p)}=x / a^{(p)}$,

$$
n_{y}^{(T)}=\left(y-y^{(T)}\right) / a^{(T)}, n_{y}^{(p)}=\left(y-y^{(p)}\right) / a^{(p)}-
$$

the coordinates of the normal unit vector to the surface of the service and recovery wells at a given point $(x, y)$.

In accordance with the adjusted technological workflow, the lower flowing well will be able to produce only after a certain period of time $t_{l}$ (let us call it the induction period), when the temperature increases (thereby a significant decrease in oil viscosity) around the well due to the functioning of the heating channel.

Then, in this period $\left(0<t<t_{1}\right)$, for reducing the counting time, we assume, that the flowing well is closed and thus the filtration flow in the reservoir will be neglected, and then we will only solve the heat conduction equation under the corresponding boundary conditions. The steady thermal field by the time $t=t_{l}$ will be taken as the initial data in the future, after the opening of the flowing well at $t=t_{l}$. Moreover, for the system of initial and boundary conditions for the parameters that describe the hydrodynamic fields (velocity and pressure) we will take the conditions according to the expressions given in (6) and (7).

For the total thermal flux from the well into the reservoir, we can write 


$$
q^{(T)}=2 \pi r_{c} \lambda\left(\frac{\partial T}{\partial x} n_{x}+\frac{\partial T}{\partial y} n_{y}\right),
$$

where $n_{x}, n_{y}$ - the coordinates of the normal unit vector to the well surface at a given point with coordinates $(x, y)$, which are defined as $n_{x}=x / r_{c}, n_{y}=y / r_{c}$. Then to calculate the thermal flux from (8), we obtain the expression

$$
q^{(T)}=2 \pi r_{c} \lambda\left(\frac{\partial T}{\partial x} \frac{x}{r_{c}}+\frac{\partial T}{\partial y} \frac{y}{r_{c}}\right) .
$$

The total heat expended will be determined from the expression

$$
Q=\int_{0}^{t} q^{(T)} d t
$$

For the mass flow from the well, we can write

$$
q^{(v)}=2 \pi r_{c} \rho_{l} m v,
$$

from which, taking into account Darcy law (2), (3), we will find out

$$
q^{(v)}=-2 \pi r_{c} \rho_{l} \frac{k}{\mu(T)}\left(\frac{\partial P}{\partial x} \frac{x}{r_{c}}+\frac{\partial P}{\partial y} \frac{y}{r_{c}}\right) .
$$

The total oil produced is determined from the expression

$$
M=\int_{0}^{t} q^{(v)} d t
$$

Numerical algorithm of the problem

For numerical implementation by the method of finite differences, the splitting scheme is adopted [7]. In accordance with this scheme, each two-dimensional equation is split into two onedimensional equations and the process of changing the parameters along the plane is replaced by two processes. In the first case, the equation is solved about the axis $O x$, and impermeable membranes are mentally introduced about the axis $O y$. Then, instead of these membranes, membranes in the $O x$ direction are introduced and the problem in the $O y$ direction is solved. For approximation of expressions, equally spaced and temporal grids are introduced. Discretization of equations is performed using an explicit scheme. The stability condition for the difference scheme was determined from the Courant condition. The curved boundary (the well) will be approximated by a stepped line, as shown in Figure 2.

It should be noted, that under this approach, the solution is in the approximate area, and at the same time the resulting error of solution (for a sufficiently narrow mesh) is negligible [8].

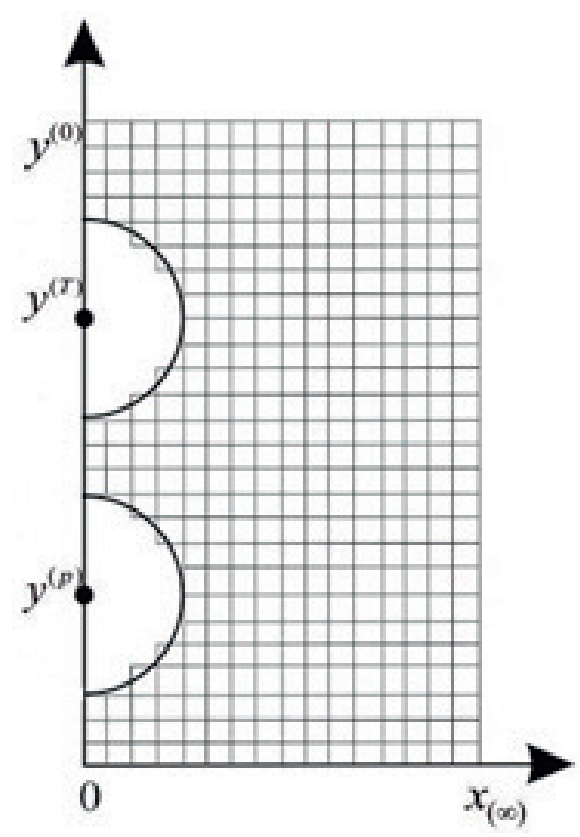

Figure 2. Meshscheme

The boundary condition at $x=0$ is carried down to the mesh boundary $x=x_{(\infty)}$. On the mesh boundary, $0<y<y^{(0)}$ from the symmetry condition it follows that $\partial T / \partial x=0, \partial P / \partial x=0$.

To obtain a numerical solution, equally spaced grids in the coordinates $x_{i}=(i-1) h_{x}$ and $y_{i}=(i-1) h_{y}\left(i=1, \ldots, N_{x}, j=1, \ldots, N_{y}\right)$ are introduced and an unequally-spaced grid in time, where for time step value $\tau$ the smallest of the values is taken

$$
\begin{gathered}
\tau_{1}=\frac{h_{x}^{2}}{2 v}, \tau_{2}=\frac{h_{y}^{2}}{2 v}, \tau_{3}=\frac{\mu h_{x}^{2} \rho c}{2 k \rho_{l} c_{l}}, \tau_{4}=\frac{\mu h_{y}^{2} \rho c}{2 k \rho_{l} c_{l}}, \\
\tau_{5}=\frac{m \alpha^{(P)} \mu h_{x}^{2}}{2 k}, \tau_{6}=\frac{m \alpha^{(P)} \mu h_{y}^{2}}{2 k} .
\end{gathered}
$$

The system of equations (5) with the postulated boundary conditions, after the substitution of the differential operators for their finite-difference analogues, will be as follows:

$$
\begin{gathered}
P_{i, j}^{k+\frac{1}{2}}=P_{i, j}^{k}+\frac{\alpha^{(T)}}{\alpha^{(P)}}\left(T_{i, j}^{k+\frac{1}{2}}-T_{i, j}^{k}\right)+ \\
+\frac{k \tau}{m \alpha^{(P)} h_{x}^{2}}\left(\frac{P_{i+1, j}^{k}-P_{i, j}^{k}}{\mu\left(T_{i+1, j}^{k}\right)}-\frac{P_{i, j}^{k}-P_{i-1, j}^{k}}{\mu\left(T_{i, j}^{k}\right)}\right), \\
P_{i, j}^{k+1}=P_{i, j}^{k+\frac{1}{2}}+\frac{\alpha^{(T)}}{\alpha^{(P)}}\left(T_{i, j}^{k+1}-T_{i, j}^{k+\frac{1}{2}}\right)+ \\
+\frac{k \tau}{m \alpha^{(P)} h_{y}^{2}}\left(\frac{P_{i, j+1}^{k+\frac{1}{2}}-P_{i, j}^{k+\frac{1}{2}}}{\mu\left(T_{i, j+1}^{k+\frac{1}{2}}\right)}-\frac{P_{i, j}^{k+\frac{1}{2}}-P_{i, j-1}^{k+\frac{1}{2}}}{\mu\left(T_{i, j}^{k+\frac{1}{2}}\right)}\right),
\end{gathered}
$$




$$
\begin{gathered}
T_{i, j}^{k+\frac{1}{2}}=T_{i, j}^{k}+\frac{k \rho_{l} c_{l} \tau}{\mu\left(T_{i, j}^{k}\right) \rho c} \cdot \frac{P_{i+1, j}^{k}-P_{i, j}^{k}}{h_{x}} \times \\
\times \frac{T_{i+1, j}^{k}-T_{i, j}^{k}}{h_{x}}+\frac{v \tau}{h_{x}^{2}}\left(T_{i+1, j}^{k}-2 T_{i, j}^{k}+T_{i-1, j}^{k}\right), \\
T_{i, j}^{k+1}=T_{i, j}^{k+\frac{1}{2}}+\frac{k \rho_{l} c_{l} \tau}{\mu\left(T_{i, j}^{k+\frac{1}{2}}\right) \rho c} \cdot \frac{P_{i, j+1}^{k+\frac{1}{2}}-P_{i, j+1}^{k+\frac{1}{2}}}{h_{y}} \times \\
\times \frac{T_{i, j+1}^{k+\frac{1}{2}}-T_{i, j}^{k+\frac{1}{2}}}{h_{y}}+\frac{\nu \tau}{h_{y}^{2}}\left(T_{i, j+1}^{k+\frac{1}{2}}-2 T_{i, j}^{k+\frac{1}{2}}+T_{i, j-1}^{k+\frac{1}{2}}\right) .
\end{gathered}
$$

Boundary conditions are of the form of:

$$
\begin{gathered}
T_{1, j}=T_{2, j}, T_{N_{x}, j}=T_{o}, T_{i, N_{y}}=T_{o}, T_{i, 1}=T_{o}, P_{1, j}=P_{2, j}, \\
P_{N_{x}, j}=p_{o}+\rho g\left(H-(j-1) h_{y}\right), P_{i, N_{y}}=P_{o}, P_{i, 1}=P_{i, 2} .
\end{gathered}
$$

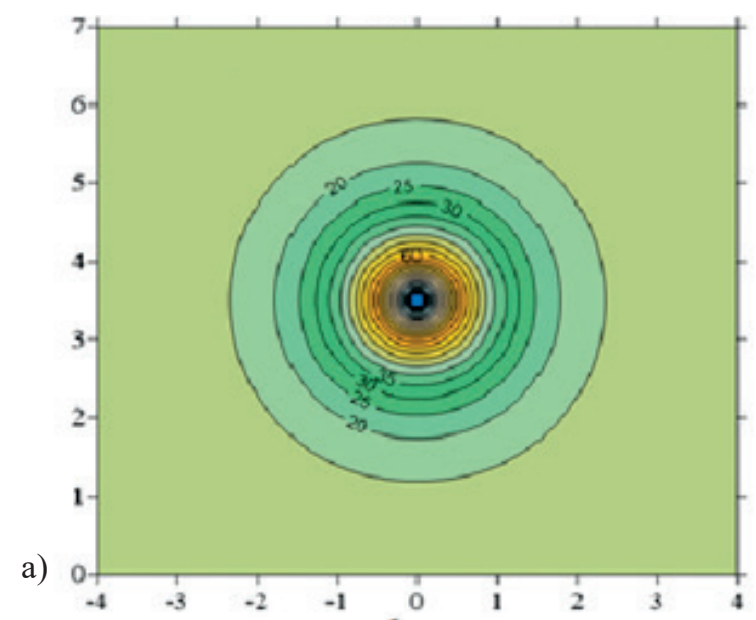

\section{The results of numerical calculations}

When performing a numerical implementation, the following parameter points are taken: $T_{c}=160^{\circ} \mathrm{C}, T_{0}=12^{\circ} \mathrm{C}, a^{(T)}=0.1 \mathrm{~m}, H=8 \mathrm{~m}$, $\lambda=1.28 \mathrm{~W} /(\mathrm{mK}), \rho c=2.5 \times 10^{6} \mathrm{~J} /\left(\mathrm{K} \mathrm{m}^{3}\right)$, $v=10^{-6} \mathrm{~m}^{2} / \mathrm{s}$.

Figure 3 shows the calculation results for the temperature field (a) and viscosity (b) of the oil reservoir after heating it for $t_{1}=10$ days. The graph shows that at this stage a heated area of about several meters appears near the boundary of heating. As the formation heats up, a decrease in oil viscosity near the well boundary occurs. The choice of formation heating time $t_{l}$ can be determined, depending on the thickness of the oil-saturated layer.

At the second stage of a pair of wells' operation $\left(t>t_{1}\right)$, namely, in the mode of oil extraction

b)

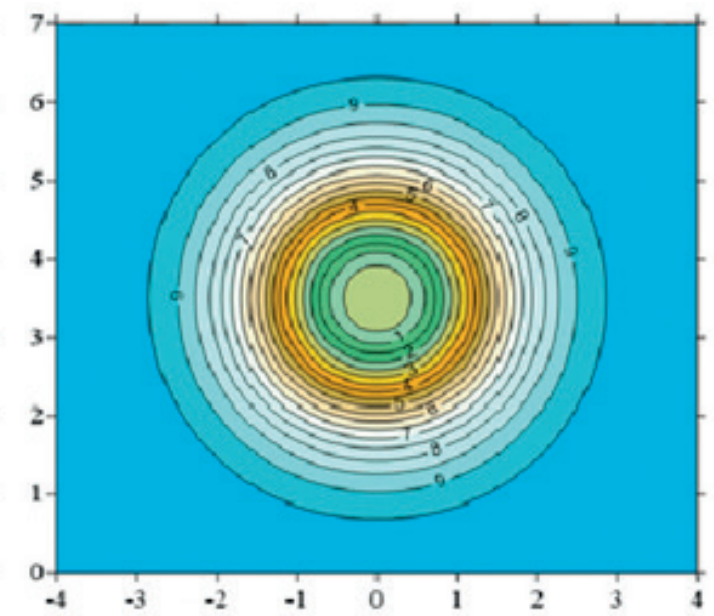

Figure 3. Temperature (a) and viscosity (b) distribution for 10 days of reservoir heating

without simultaneous heating through the injection well, at which a heated crude with thinned out viscosity is near the flowing well of radius $a^{(p)}$, the distance between the injection and flowing wells we take equal to $l=y^{(T)}-y^{(p)}$.

When performing a numerical implementation, the following parameter points were used: $p_{0}=0.5 \mathrm{MPa}, p_{c}=0.3 \mathrm{MPa}, \rho_{l}=980 \mathrm{~kg} / \mathrm{m}^{3}$, $c_{1}=1400 \mathrm{~J} /(\mathrm{Kkg}), \alpha^{(T)}=10^{-5} \mathrm{~K}^{-1}, \alpha^{(p)}=5 \times$ $\times 10^{-9} \mathrm{~Pa}^{-1}, k=10^{-12} \mathrm{~m}^{2}, m=0.3, a^{(p)}=0.1 \mathrm{~m}$, $\ell=0.5 \mathrm{~m}$.

Figure 4 represents a graphic illustration of the pressure field $(a)$, velocities $(b)$ and temperature (c) at 4 hours after the start of oil extraction. The formation heating time is $t_{1}=10$ days.

It is seen that the movement of the filtration boundary takes place at the velocity, significantly higher than the velocity of the heating boundary.
Thus, the mode with concurrent heating or without it during the studied time (4 hours) has no time to exert any noticeable effect on the straining action.

Figure 5 represents the pressure profiles, temperature, and viscosity in section of the reservoir in the coordinate $x=0$ at time $t_{1}=10$ days after heating without sampling (line 1 ) and $t_{2}=4$ hours after oil sampling (line 2).

Figure 6 shows the time dependence of the thermal flux $q^{(T)}(a)$ and the total consumed heat $Q$ (b). It can be seen that in the initial period of heating the formation, for thermostatic control in the well, the largest heat input is required.

Figure 7 shows the dependence of the flow rate $q^{(\mathrm{v})}(a)$ and the total production rate $M(b)$ on time $t$. 
a)

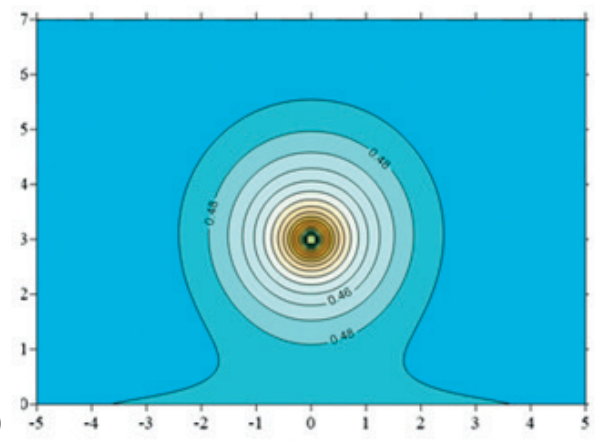

b)

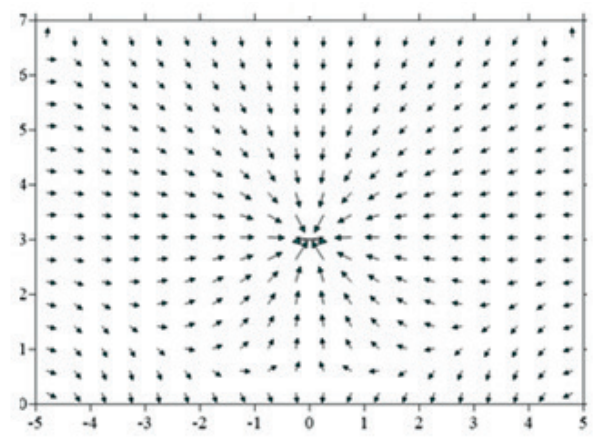

c)

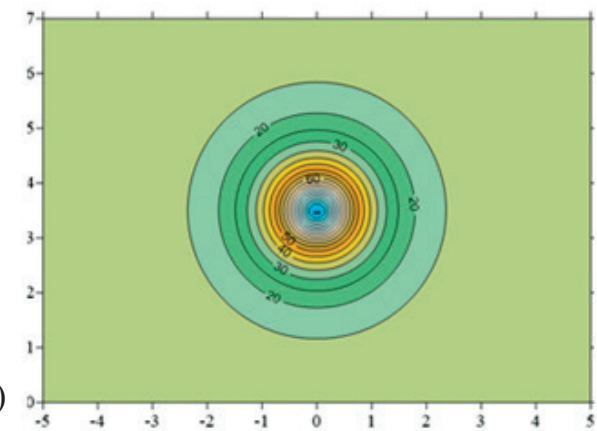

Figure 4. Pressure fields (a), velocities (b) and temperature (c) for 4 hours of oil drainage in the absence of heating
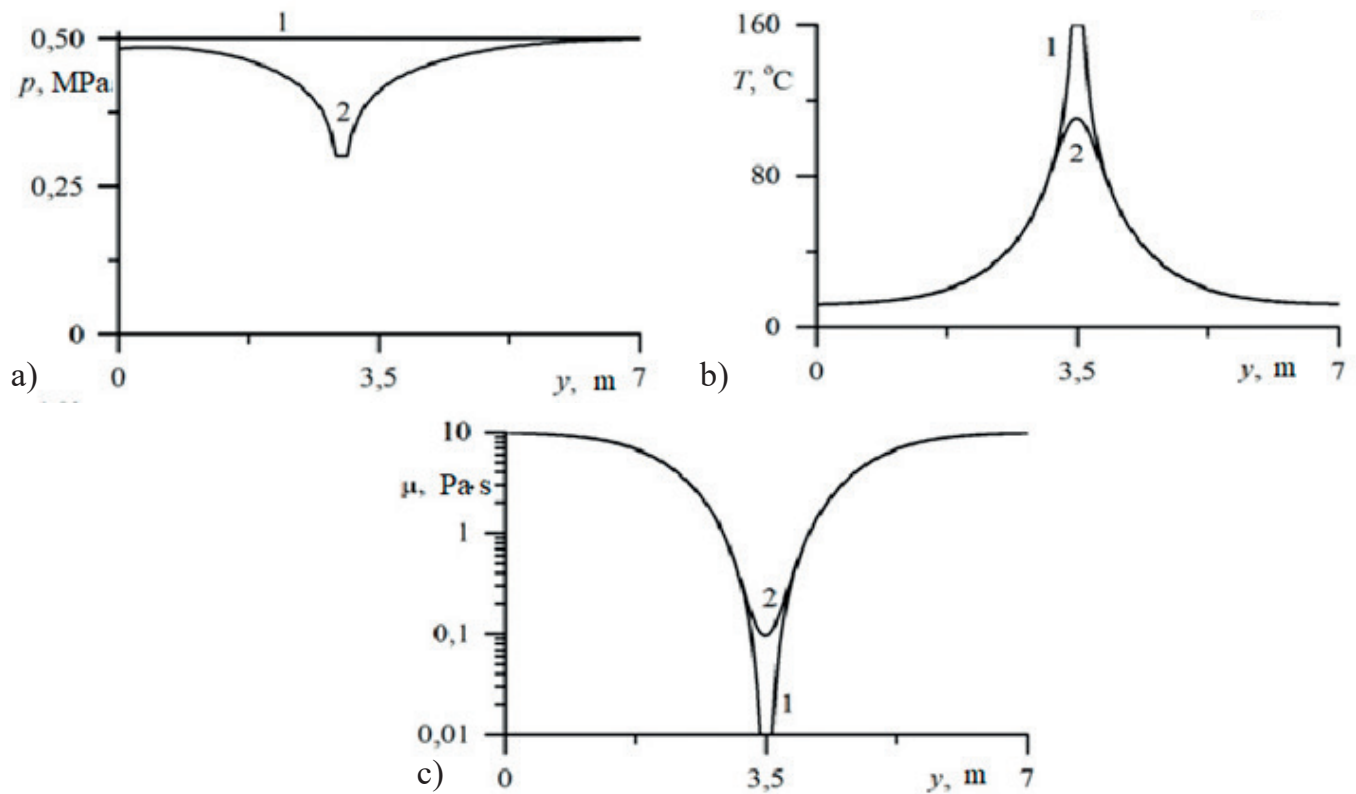

Figure 5. Pressure fields (a), temperature (b) and viscosity $(c)$ in section of the reservoir in the coordinate $x=0$ at time $t_{1}=10$ days after heating without sampling (line 1 ) and $t_{2}=4$ hours after oil sampling (line 2)
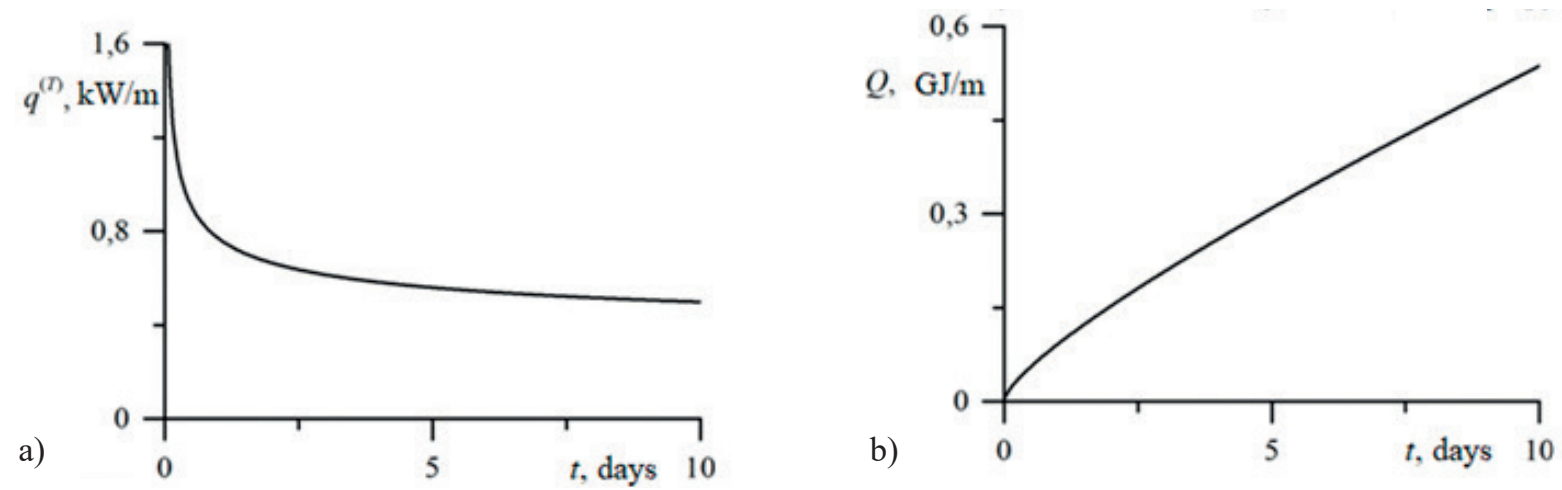

Figure 6. The dynamics of thermal flux (a) and the total consumed heat (b) for 10 days of reservoir heating 

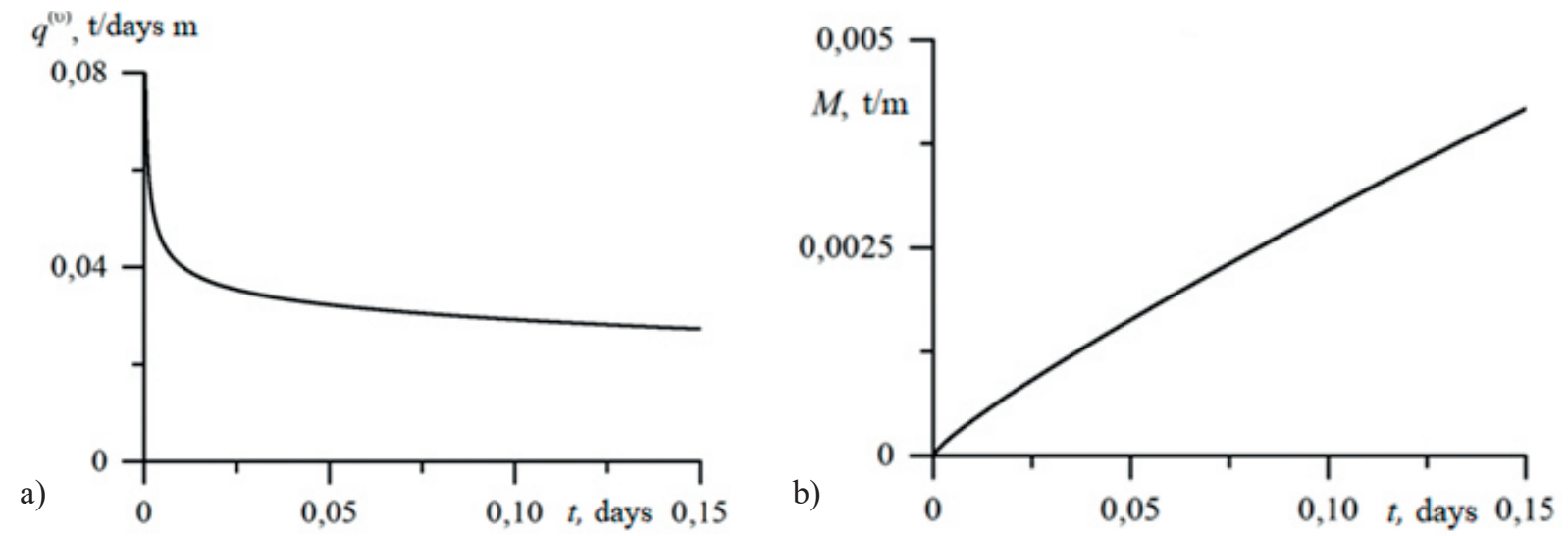

Figure 7. The dynamics of the flow rate $(a)$ and the total production rate $(b)$ for 4 hours of the flowing well operation

Thus, with heating effect to the oil reservoir, the most important parameters are the lower commercially extractable oil production rate, as well as the potential efficiency of investments in field development with unconventional oil. The results obtained in this problem allow us to obtain the approximate data for energy efficiency assessment during thermal treatment in certain geological and physical features of the oil reservoir.

\section{Conclusions}

Based on the research results, the following conclusions were formulated.

1. In a two-dimensional statement, the problem of an oil reservoir heating, containing highviscosity oil is solved using the technology of double horizontal wells, according to which the thermal fluid is injected into the upper injection well, and liquefied heated oil is withdrawn from the lower flowing well. The differential equation system for pressure and temperature was obtained, taking into account the gravitational effect, which is solved by the method of finite dif-

\section{REFERENCES}

1. Burzhe Zh., Surio P., Kombarnu M. Termicheskie metody povysheniya nefteotdachi plastov [Thermal Enhanced Oil Recovery Methods]. Moscow, Nedra Publ., 1988. 421 p. [in Russian].

2. Baibakov N.K., Garushev A.R. Teplovye metody razrabotki neftyanykh mestorozhdenii [Thermal Methods of Oil Field Development]. Moscow, Nedra Publ., 1981. 286 p. [in Russian].

3. Mirzadzhanzade A.Kh., Kovalev A.G., Zaitsev Yu.V. Osobennosti ekspluatatsii mestorozhdenii anomal'nykh neftei [Features of the Operation of Anomalous Oil Fields]. Moscow, Nedra Publ., 1972. 200 p. [in Russian].

4. Butler R.M., Jiang Q. Improved Recovery of Heavy Oil by Vapex with Widely Spaced Horizontal Injectors and Producers. Journal of Canadian Petroleum Technology, 2000, Vol. 39, Issue 1, pp. 48-56. DOI: 10.2118/00-01-04.

ferences using a splitting scheme. Discretization of equations using an explicit schemeis performed.

2. For the initial stage of reservoir development, the performance evaluation of high-viscosity oil recovery was conducted, with the use of two horizontal wells, working alternately. Evaluation of the effectiveness of this method for longer times can be performed by extrapolating the obtained solutions. The performance evaluation of this method for a long stretch of timecan be performed by method of obtained solutions extrapolation. The obtained results allow us to give approximate data on the energy efficiency of thermal effect on the formation, depending on its geological and physical features.

This work was provided as part of a state assignment in the field of scientific activity № FEUR-2020-0004. The title of the project is "The solution of topical problems and the process study in petrochemical industries, accompanied by multiphase flow».

5. ZheltovYu.P. Mekhanika neftegazonosnogo plasta [Oil and Gas Reservoir Mechanics]. Moscow, Nedra Publ., 1975. 216 p. [in Russian].

6. Nigmatulin R.I. Dinamika mnogofaznykh sred [Dynamics of Multiphase Media]. Moscow, Nauka Publ., 1987. 464 p. [in Russian].

7. Shagapov V.S., TazetdinovaYu.A., Gizzatullina A.A. K teorii razrabotki mestorozhdenii vysokovyazkoi nefti s ispol'zovaniem teplovogo vozdeistviya [On the Theory of the Development of High-Viscosity Oil Deposits Using Heating]. Prikladnaya mekhanikaitekhnicheskaya fizika - Journal of Applied Mechanics and Technical Physics, 2019, Vol. 60, No. 5 (357), pp. 117-124. DOI: 10.15372/PMTF20190511. [in Russian].

8. Samarskii A.A. Teoriya raznostnykh skhem [Dif ference Scheme Theory]. Moscow, Nauka Publ., 1977. 656 p. [in Russian] 


\section{СПИСОК ИСПОЛЬЗУЕМЫХ ИСТОЧНИКОВ}

1. Бурже Ж., Сурио П., Комбарну М. Термические методы повышения нефтеотдачи пластов. М.: Недра, $1988.421 \mathrm{c}$.

2. Байбаков Н.К., Гарушев А.Р. Тепловые методы разработки нефтяных месторождений. М.: Недра,1981. $286 \mathrm{c}$.

3. Мирзаджанзаде А.Х., Ковалев А.Г., Зайцев Ю.В. Особенности эксплуатации месторождений аномальных нефтей. М.: Недра, 1972. 200 с.

4. Butler R.M., Jiang Q. Improved Recovery of Heavy Oil by Vapex with Widely Spaced Horizontal Injectors and
Producers // Journal of Canadian Petroleum Technology. 2000. Vol. 39. Issue 1. P. 48-56.DOI: 10.2118/00-01-04.

5. Желтов Ю.П. Механика нефтегазоносного пласта. М.: Недра, 1975. 216 с.

6. Нигматулин Р.И. Динамика многофазных сред. М.: Наука, 1987. 464 с.

7. Шагапов В.С., Тазетдинова Ю.А., Гиззатуллина А.А. К теории разработки месторождений высоковязкой нефти с использованием теплового воздействия // Прикладная механика и техническая физика. 2019. T. 60. № 5 (357). C. 117-124. DOI: 10.15372/PMTF20190511.

8. Самарский А.А. Теория разностных схем. М.: Наука, 1977. 656 с.

\section{ABOUT THE AUTHORS СВЕДЕНИЯ ОБ АВТОРАХ}

Alina A.Gizzatullina, Candidate of Physical and Mathematical Sciences, Lecturer of Information Technologies, Mathematics and Natural Sciences Department, USPTU, Branch, Oktyabrsky, Republic of Bashkortostan, Russian Federation

Гиззатуллина Алина Азатовна, канд. физ.-мат. наук, преподаватель кафедры информационных технологий, математики и естественных наук,УГНТУ, филиал, г. Октябрьский, Республика Башкортостан, Российская Федеращия

e-mail:alina.gizzatullina87@mail.ru

Yulia A. Tazetdinova, Candidate of Physical and Mathematical Sciences, Senior Lecturer of Informatics and Economics Department, BashSU, Branch, Birsk, Republic of Bashkortostan, Russian Federation

Тазетдинова Юлия Александровна, канд. физ.-мат.наук, стариий преподаватель кафедры информатики и экономики, БашГУ, филиал, г. Бирск, Республика Башкортостан, Российская Федерация

e-mail:ym_julia@mail.ru

Bulat I. Tazetdinov, Candidate Physical and Mathematical Sciences, Assistant Professor of Informatics and Economics Department,BashSU, Branch, Birsk, Republic of Bashkortostan, Russian Federation

Тазетдинов Булат Ильгизович, канд. физ.-мат.наук, доцент кафедры информатики и экономики, БашГУ, филиал, г. Бирск, Республика Башкортостан, Российская Федерация

e-mail:bulatbirsk@yandex.ru 